\title{
Summary
}

If the structure of kainic acid, the anthelmintic principle of Digenea simplex Ag., is as shown below, various reactions listed in Table $\mathrm{I}$ would be explained well.

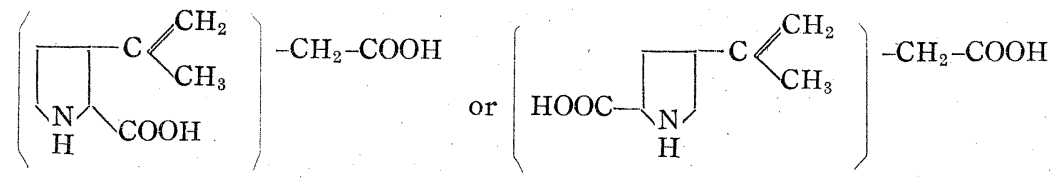

(Received April 8, 1955)

219. 村上信三, 竹本常松, 鄭 然昌, 醍醐晧二：海人草有効成分の研究（第 9 報） カイニン酸の構造につレて その 2

Shinzo Murakami, Tsunematsu Takemoto, Zensho Tei, and Koji Daigo : Studies on the Effective Principles of Digenea simplex Ag. IX.

Structure of Kainic Acid. (2).

(Pharmaceutical Institute, Medical Faculty, University of Osaka)

著者等は先にカインン酸の構造を<smiles>CCCCCCCC(C)C1CC(C(=O)O)NC1C(=O)O</smiles>

と推定したが，とれで考えられる可能な平面的構造式を列挙すれば Table I に示与よらになる.

Table I. Assumed Structures of Kainic Acid<smiles>CC(C)C1CC(CC(=O)O)NC1C(=O)O</smiles>

(a)<smiles>CC(C)C1CC(C(=O)O)NC1CC(=O)O</smiles>

(b)<smiles>CC(C)C1C(CC=O)CNC1C(=O)O</smiles>

(c)

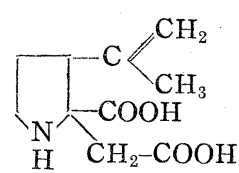

(d)<smiles>CC(C)C1CC(CC(=O)O)(C(=O)O)CN1</smiles>

(e)<smiles>CCC(CC(=O)O)(C(=O)O)C(C)C</smiles>

(f)<smiles>CC(C)C1(CC(=O)O)CNC(C(=O)O)C1</smiles>

(g)<smiles>CC(C)C1CNC(C(=O)O)C1CCOCCO</smiles>

(h)

著者等は実験の部に記載するよらな各種誘導体を検討した結果，カイニン酸について次のよらな事実を明らか

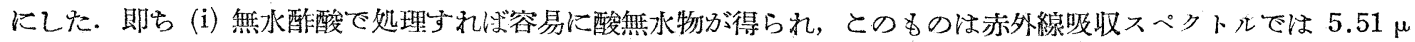
と $5.65 \mu$ に吸収が認められるので六員環無水物であると考之られる*. (ii) カイニン酸を塩酸て处理すればその 異性体と思われる仮称 $\mathrm{N}$ 酸 (VII) と $\mathrm{C}_{10} \mathrm{H}_{15} \mathrm{O}_{4} \mathrm{~N}$ の組成を有するラクトン体 (VIII) ガ得られる. とのラクトン体は

* N-phenylacetylglutamic anhydride は $5.50 \mu を 5.60 \mu$ と吸取が認めら扎る [J. A. King et al.：J. Am. Chem. Soc. 74, 5202 (1952)]. 
赤外線吸収スペクトルでは $5.80 \mu$ に吸収が認められるのて $\delta$-ラクトン体で女ると考えられる. (iii) カインン 酸は Hof mann 分解を受けつけない. 以上の事奏を考慮して前揭の 8 種の式を検討すれば，(a)では酸無水物は 7 員環となり (i) の事实と矛盾する。また 基がついて Hof mann 分解が多少は困難となるととが考えられても，全然出来ない点も直肯し難い**. (b)，(d)，

Table II. Reactions of Kainic Acid<smiles>CCCCCCCCCCCC(C)(C)OC(=O)CC1C2CNC(C(=O)O)C1C2</smiles>

(VII)<smiles>C=C(C(=O)OCC(=O)O)C1CC(=O)OC(=O)N(C(C)=O)C[C@H]1C(=C)C</smiles>

(II) $\stackrel{\mathrm{l}}{\mathrm{C}} \mathrm{H}_{3}$

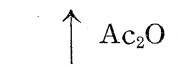<smiles>COC(=O)C(CBr)CBr</smiles>

(IX)<smiles>CCC(C)C1CNC(C(=O)O)C1CC(=O)O</smiles><smiles>CCCCCCCC</smiles>

(III)<smiles></smiles>

(VI)<smiles>CC(C)C1CN=C(C(=O)O)C1CC(=O)O</smiles>

(IV) $\mathrm{H}$

$\downarrow \mathrm{CH}_{3} \mathrm{OH}+\mathrm{HCl}$<smiles>CC(C)C1C[NH+](C(=O)O)C2CC(=O)OC1C2</smiles>

(v) $\stackrel{\mathrm{I}}{\mathrm{C}} \mathrm{H}_{3}$<smiles>COCCC1C(C(=O)OC)=NCC1C(C)C</smiles>

(X) $\mathrm{H}$<smiles>CCCCCCCC</smiles><smiles>COC(=O)CC1C(C(C)C)CN(C)C1C(=O)OC</smiles>

(XI) $\stackrel{\stackrel{1}{\mathrm{C}}}{6} \mathrm{H}_{5}$<smiles>COC(=O)CC1C(C(C)C)CNC1C(C)C</smiles><smiles>CC(C)[IH]CO[AsH3]</smiles><smiles>COC(=O)CC1C(C(C)C)C=NC1C(C)(C)O</smiles>
(XIII)

(XII)<smiles>CCCC</smiles>
distill.<smiles>COCCC1C(C(C)C)C=[N+](C)C1C(=O)OC</smiles>

\footnotetext{
*** tropinic acid は円滑に Hofmann 分解を受ける〔R. Willstätter：Ber. 28, 3271 $\mathrm{H}_{2} \mathrm{C} \mathrm{N}^{\prime}$ COOH (1895)]. HOOC $\mathrm{CH}_{3}$
} 
(e), (g) では $\delta$-ラクトン体の生成は説明出来るが, 酸無水物は 5,7 または 8 員環としてのみ可能で岁りま た Hofmann 分解の困難なととも理解し難い. (c) で $\delta$-ラクトン体の生成及び Hofmann 分解の点は首肯出 来るが，酸無水物は 7 または 8 員環とならざるを得ない（f）酸無水物の 6 員環となるととは可能で女つて

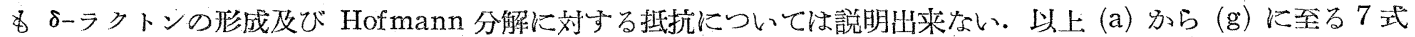
厄゙カイニン酸の示す諸反応説明するには不適切で女る。最後の (h) 厄恔 Table II に示すよ5に酸無水物は 6 員環となること， グルタミン酸とイソペンテンを考慮に入れた biogenesis の観点からす與味深いるのが岁る。

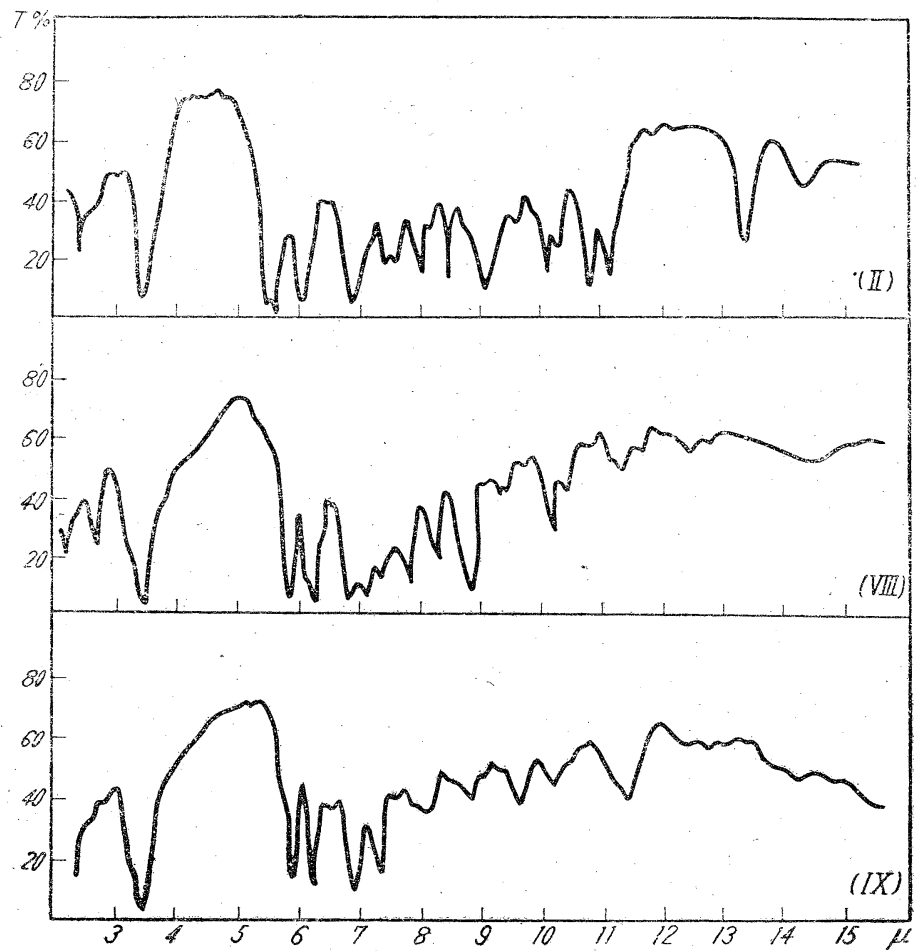

Fig. 1. Infrared Spectra of N-Acetylkainic Acid Anhydride (II), Kainic Acid Lactone (DII), and Bromokainic Acid Lactone (IX) (in Nujol)

本研党に当り赤外線吸取スペクトル湘定の労をこられた大阪书立大学理工学部赤外分析空及び武时渠工研觉

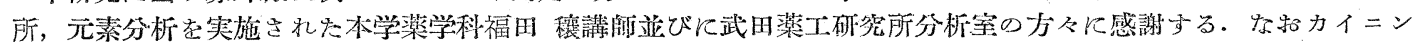

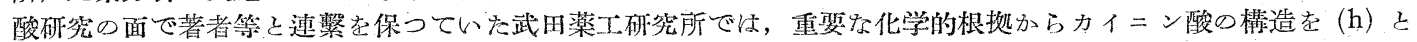
決定した旨，本稿起草前に著者等に通報せられて。併せてここに感謝の意を表する。

\section{実驗。の 部}

$\mathrm{N}$ ーアセチルカイニン酸無水物 (II) 及び対応する遊離酸 (III) よく乾燥したカイニン酸 $10 \mathrm{~g}$ に無水酰酸 30

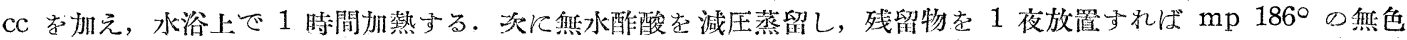
板状ををは桂状結晶 (II) $6.5 \mathrm{~g}$ を得. 本品はニンヒドリン反応陰性, 赤外線吸取スペクトルでは $5.51 \mu$ 及び $5.65 \mu$ 飞吸収が認められる。 $\mathrm{C}_{12} \mathrm{H}_{15} \mathrm{O}_{4} \mathrm{~N}$ 計算值 $\mathrm{C} 60.75, \mathrm{H} \mathrm{6.37,} \mathrm{N} 5.90$, 实験值 $\mathrm{C} 61.30, \mathrm{H} 6.18$, $\mathrm{N}$ 5.81. 本品は水からの再結晶により $\mathrm{mp} 202^{\circ}$ の無色短柱状結晶 (III) となる. $\mathrm{C}_{12} \mathrm{H}_{17} \mathrm{O}_{5} \mathrm{~N}$ 計算値 $\mathrm{C} 56.46$,

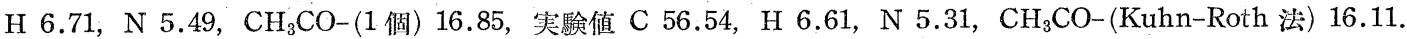

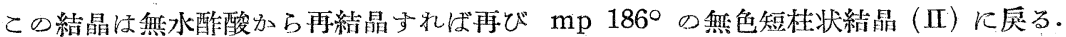

N-アセチルジヒドロカイニン酸 (VI) N-アセチルカイニン酸 $1.75 \mathrm{~g}$ を $100 \mathrm{cc}$ の水によかし，10\%パラジ ウム炭 $1 \mathrm{~g}$ を加六水素符流中で接触還元すれば 40 分間で $160 \mathrm{cc}$ (計算量 $153.6 \mathrm{cc}$ ) の水素を吸収して反応は終

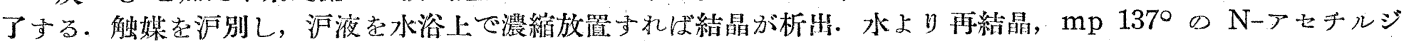
七ドロカイニン酸の重色短桂状結晶 (VI) $0.8 \mathrm{~g}$ 起得. $\mathrm{C}_{12} \mathrm{H}_{19} \mathrm{O}_{5} \mathrm{~N}$ 計算值 $\mathrm{C} 56.02, \mathrm{H} 7.44, \mathrm{~N} 5.44, \mathrm{CH}{ }_{3} \mathrm{CO}-$ 
(1 個) 16.72, 实験値 C 55.68, H 7.51，N 5.16, $\mathrm{CH}_{3} \mathrm{CO}-(\mathrm{Kuhn}-\mathrm{Roth}$ 法) 16.15 .

N-アセチルジヒドロカイニン酸無水物 $(\mathbf{V})$ 及び対応する遊離酸 $(\mathbf{V I})$.

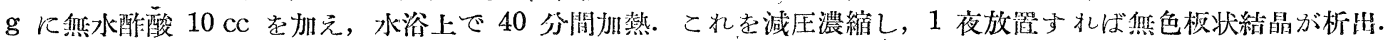
得量 $1.5 \mathrm{~g}$. 無水酢酸より再結晶, $\mathrm{mp} 184^{\circ}$ の然色板状結晶 $(\mathrm{V}) . \mathrm{C}_{12} \mathrm{H}_{17} \mathrm{O}_{4} \mathrm{~N}$ 計算值 $\mathrm{C} 60.24, \mathrm{H} 7.16, \mathrm{~N}$

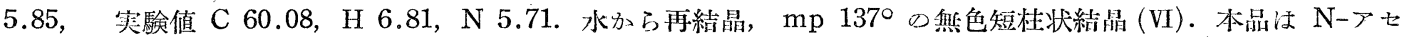
チルカイニン酸を水素化して得られる $\mathrm{N}-$ チチルジヒドロカイニン酸こ混融して融点降下出ず.む真空中に

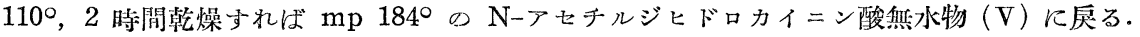

カイニン酸の塩酸処理 カイニン酸 $5.3 \mathrm{~g}$ に莀塩酸 $32 \mathrm{cc}$ を加え, 水浴上で 3 時閒州熱. 反応物は直ちに 減压で蔡発乾固し，塩酸を出来るだけ除いた後 $50 \mathrm{cc}$ の水によかし，酸化銀を加えて振りクロルイオンを完全に 除去. 沪液に硫化水素を通じて脱銀し，得られる水溶液を蒸発数縮し，酢酸銅飽和水溶液を加え水浴上で加温す ると深藍色の沈澱を生ずる。過剩の䣷酸銅溶液を加えても，もはや沈澱が生じなくなれば沈澱を沪取しょく水洗 し，洗液は沪液さ合する。

a) $\mathbf{N}$ 酸 (VII)* 醀酸銅溶液による洮搌を水 $150 \mathrm{cc}$ に浮游させ，硫化水素で脱銅する. 沪液さ水浴上で蒸 発濃縮すれば短杜状結晶約 $2 \mathrm{~g}$ を得る. 水上り再結晶, $\mathrm{mp} 253 \sim 255^{\circ}$ の算色短杜状結晶. 得量 $1.5 \mathrm{~g}$. [ $\left.\alpha\right]_{\mathrm{D}}^{25}$ : $+2.5^{\circ}$ ( $\mathrm{c}=3.0$, 水). 過マンガン酸カリ溶液及びブロム水を冷時直ちに脱色する. 本品は重曹水に発泡して溶解 し, ニンヒドリンにより黄色を呈し, 濃厚水溶液の場合は赤褐色の沈澱を生ずる.本品は結晶水を含有しない. $\mathrm{C}_{10} \mathrm{H}_{15} \mathrm{O}_{4} \mathrm{~N}$ 計算值 $\mathrm{C} 56.32, \mathrm{H} 7.09, \mathrm{~N} 6.57$, 实験值 C $56.75, \mathrm{H} 6.95, \mathrm{~N} 6.93$.

b) ラクトン体 $(\mathrm{VIII}) * *$ 銅塩を分離した沪液部を硫化水素で脱銅し, 沪液を蒸発乾固し, 少量の水より再 絬晶, $\mathrm{mp} 272 \sim 274^{\circ}(\mathrm{decomp})$ の絹系状結晶, 得量 $2 \mathrm{~g}$. $[\alpha]_{\mathrm{D}}^{24}:-7.8^{\circ}(\mathrm{c}=11.0$, 水). 本品は重曹水で発泡が

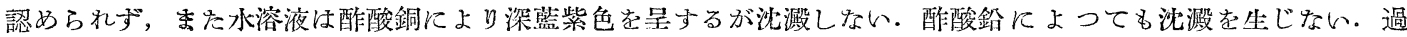
マンガン酸カリ溶液及びブロム水を正ちに脱色せず，塭化鉄溶液に対しては冷時是色也ず，加温すれば黄褐色を

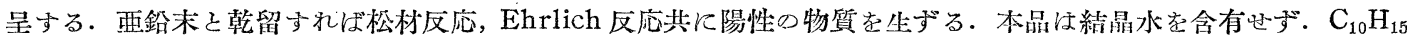
$\mathrm{O}_{4} \mathrm{~N}$ 計算值 $\mathrm{C} 56.32, \mathrm{H} 7.09, \mathrm{~N} 6.57$, 实験値 C 56.04, H 7.10, N 6.26.

ブロムラクトン体 $(\mathbf{I X}) \quad$ カイン酸 $6 \mathrm{~g}$ を水 $375 \mathrm{cc}$ に溶かし，外部から冷却しながら $2.5 \%$ の゙ロ ム水 $200 \mathrm{cc}$ 岂滴加する. 次に酸化銀を加えて覮拌し生成したブロム水素を除き，沪液を硫化水素で脱銀し減圧濃縮す ると粗結晶 $2 \mathrm{~g}$ を得. 水から再結唱, $\mathrm{mp} 244^{\circ}$ の無色針状結晶, 得量 $0.7 \mathrm{~g}$. 本品はニンヒドリン反応黄色, 結 晶水を含有过ず．ラクトン滴定するに計算量の $105.6 \%$ アルカリを消費する。 $\mathrm{C}_{10} \mathrm{H}_{14} \mathrm{O}_{4} \mathrm{NBr}$ 計算值 $\mathrm{C} 41.11$, $\mathrm{H} 4.83, \mathrm{~N} 4.79, \mathrm{Br} 27.35$, 实験值 C $41.13, \mathrm{H} 5.03, \mathrm{~N} 4.68, \mathrm{Br} 27.11$.

プロムラクトン体 $(\mathbf{I X})$ の脱プロム，カイニン酸 $(\mathbf{I})$ の再生 ブロムカイニン酸ラクトン $0.5 \mathrm{~g}$ を $70 \mathrm{cc}$ の

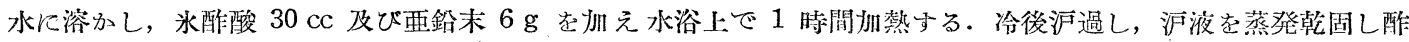
酸奥が然くなるまで水を加えて蒸発乾圆を繰返し，残渣を水に浮游させ硫化水素で脱亜鉛し，沪液を濃縮すれば $\mathrm{mp} 252^{\circ}$ の䑯色針状結晶約 $0.05 \mathrm{~g}$ を得. 本品はカイニン酸と混融して融点降下せず，なた PPCによりカイニ ン酸と同一の Rf 值走す。 $[\alpha]_{\mathrm{D}}^{29}:-10.0^{\circ}$ ( $\mathrm{c}=3.33$, 水). $\mathrm{C}_{10} \mathrm{H}_{15} \mathrm{O}_{4} \mathrm{~N}$ 計算值 $\mathrm{C} 56.32, \mathrm{H} 7.09, \mathrm{~N} \mathrm{6.57}$, 実験值 C 56.19, H 7.06, N 6.33.

ジヒドロカイニン酸ジメチルエステル $(\mathbf{X}) \quad$ よく乾燥したジヒドロカイニン酸 $5 \mathrm{~g}$ を舤水メタノール $100 \mathrm{cc}$

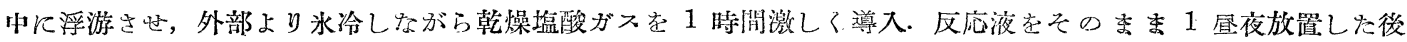

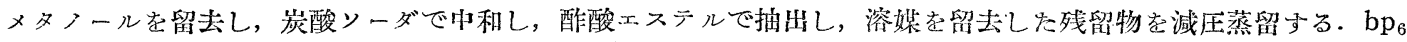
$145^{\circ} . \mathrm{C}_{12} \mathrm{H}_{21} \mathrm{O}_{4} \mathrm{~N}$ 計算值 $\mathrm{C} 59.24, \mathrm{H} 8.70, \mathrm{~N} 5.76$, 实験值 C 59.18, H 8.56, N 5.57.

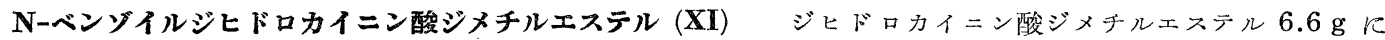

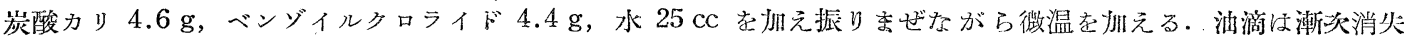
し，器壁に白色油状物が析出し，放置すれば固化する。粗結晶の得量 $8 \mathrm{~g}$. エーテルょり再結晶, $\mathrm{mp} 93^{\circ}$ の無 色針状絬晶. 得量 $5.5 \mathrm{~g} . \mathrm{C}_{19} \mathrm{H}_{25} \mathrm{O}_{5} \mathrm{~N}$ 計算值 $\mathrm{C} 65.69, \mathrm{H} 7.25, \mathrm{~N} 4.03$, 实験值 $\mathrm{C} 65.79, \mathrm{H} 7.21, \mathrm{~N} 3.95$.

ジヒドロカイニン酸ジメチルエステルメチルメチオダイド (XII) ジヒドロカイニン䧈ジメチルエステル 6

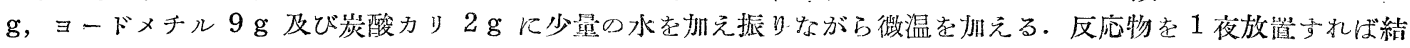
晶状に固化し, 約 $6 \mathrm{~g}$ の粗結晶が得ら礼る.メタノールから再結晶, $\mathrm{mp} 164.5^{\circ}$ の雏色桂状結晶 (XII). $\mathrm{C}_{14} \mathrm{H}_{26}$ $\mathrm{O}_{4} \mathrm{NI}$ 計算值 $\mathrm{C} 42.17, \mathrm{H} 6.56, \mathrm{~N} 3.50$, 实験值 $\mathrm{C} 41.89, \mathrm{H} 6.81, \mathrm{~N} 3.88$.

Hofmann 分解の試み ジヒドロカイニン酸ジメチルエステルメチルメチオダイド $3 \mathrm{~g}$ を少量の水に溶かし 酸化銀を加えてよく振り沪過し，沪液を減圧下蒸発乾固し，残留物を油浴中で蒸留すれば $\mathrm{bp}_{4} 135$ 〜 $145^{\circ}$ の油状 物質 $(\mathrm{XIV})$ 約 $1.1 \mathrm{~g}$ を得. $\mathrm{C}_{13} \mathrm{H}_{23} \mathrm{O}_{4} \mathrm{~N}$ 計算值 $\mathrm{C} 60.68, \mathrm{H} 9.01, \mathrm{~N} 5.44$, 实験倠 $\mathrm{C} 60.18, \mathrm{H} 8.85, \mathrm{~N}$ 5.22. 本品は二重結合を有せず， ヨードメチルを加えて常温に放置すれば暫時にして固化. 少量の水から再結晶，

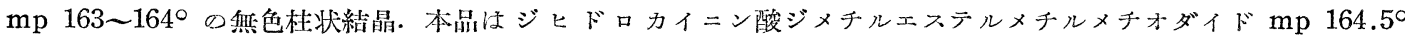
と混融して融点降下せず. 即ち Hofmann 分解の進行は認められない。

大阪大学医学部薬学科

* カイニン酸との関係が不明なので, 仮に N 酸こ呼ぶことにする.

**さき DAL (digenic acid lactone の略) と仮称していたもの[本誌 74, 268 (1954)]. 


\section{Summary}

Examination of various properties of kainic acid and its derivatives, and their infrared absorption spectra produced conclusive evidence that 2-carboxy-3-carboxymethy14-isopropenylpyrrolidine, the structure determined by the Takeda Research Laboratory and privately shown to the present writers, would be the most appropriate structure for kainic acid and that it enabled explanation of various reactions listed in Table II.

(Received April 8, 1955)

220. 高原篤夫, 谷口 繁：ペーパー・クロマトグラフィーによる薬品試験 (第 9 報1) 光電光度計による沪紙上展開物質の直接定量法*

Atsuo Takahara and Shigeru Taniguchi : Test of Drugs by Paper Partition Chromatography. IX. A Direct Quantitative Determination of Substances on Paper Chromatogram by Electrophotometer.

(Osaka Municipal Higashi Citizens' Hospital**)

ペーパー・クロマトグラフィーによつて沪紙上に分離しを各成分を定量する方法としては, 物質像の長さ, 面積 等 $\left.{ }^{2}, 3\right)$ を測定して算出する方沠以外に, 展開部位から適当な方法で各成分を抽出して滴定 ${ }^{4}$, 比色 ${ }^{5)}$ 又は bioassay ${ }^{6}$ 等による化学的, 物理的或は生物学的定量法があるが, 何れにしても対象が $\gamma$ 単位の少量物質であり原理は正確 に見えて子技術的な面で相当な実験誤美を免かれ得ない。

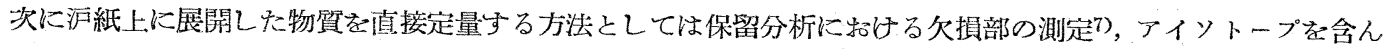
ゲ有機化合物の分別带の放射能の測定 8 等の特定な場合を除いて, 呈色部の濃度を光学的に測定与る方法が試み られている，例えば祖父江，旗野》は水銀燈の青紫色フィルタ一通過光を糖の呈色部に出て，その透過光度と糖 量の関係を求めたととろ沪紙の不均一性のため結果が不規則に出てとれを定量法に採用するととは出来ないが, 反射率と試料の量との間には一定の関係を有するととを認めている. 梅村10) はアミノ酸のニンヒドリン呈色部に 極く細い光線を岁て，その最大吸収部圭測定して一応の量的関係を求め, Grassmann, Hanning ${ }^{11)}$ は血清の沪 紙電気泳動圆に白色光を岕て, アルブミンとグロブミンの量的相関性を求めて物り，他にアミノ酸のデンシトメ トリーに関しては数種の報告がある。また橋本, 森 $\left.{ }^{12}\right)$ は自製の紫外線パピログラフ装置を用いて沪紙上物質を検 掌するために描いた紫外線パピログラフィーの山の面積或はその高さが定量関係に岁るととを予想して特り，デ ンシトメーターによる透過光, 反射光或は䖝光等の測定が試みられつつある. 一方著者等は沪紙の条件を詳細に 検討し，汇紙上に展開した物質を直接比色定量し得る光電光度計を設計自製し満足な結果を得た.

即ち測定に差支えない範囲の単色光が細詙いスリットを通して適当に呈色せしめた展開沪紙の幅一ぱいに当る 樣に設計した．汇紙は透過率を向上させるため予め流動パラフィン处理を施し，とのものをガラス板に摤んでス

* 第 74 回日本薬学会年会 (1954) で発表. ** Sugiyama-cho, Higashi-ku, Osaka.

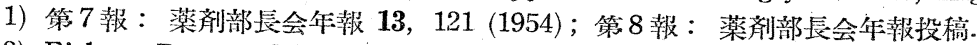

2) Fisher, Parson, Morison: Nature 161, 764 (1948).

3) Fisher, Parson, Holmes: Nature 164, 183 (1949).

4) Hawthrone: Nature 160, 715 (1947). 5) Cavallini, Frontali, Toschi : Nature 163, 568 (1949).

6) Goodall, Levi : Nature 158, 675 (1946). 7) Tomarelli, Florey: Science 107, 630 (1948).

8) Wieland, Wirth: Angew. chem. 63, 473 (1950). 9) 祖父江, 籏野: 工化 54, 460 (1951).

10) 梅村：医学已生物学 19, 250 (1951). 11) Grassman, Hannig : Z. physiol. chem. 290, 1 (1952).

12) 橋本, 森: Nature 170, 1024 (1952). 